\title{
FTIR spectroscopy, chemical and histochemical characterisation of wood and lignin of five tropical timber wood species of the family of Dipterocarpaceae
}

\author{
Rumana Rana $\cdot$ Rosemarie Langenfeld-Heyser • \\ Reiner Finkeldey · Andrea Polle
}

Received: 12 July 2008/Published online: 29 August 2009

(C) The Author(s) 2009. This article is published with open access at Springerlink.com

\begin{abstract}
The goal of this study was to characterise chemical and histochemical properties of five dipterocarp timber wood species (Dipterocarpus kerrii, Hopea plagata, Parashorea malaanoman, Shorea almon, and Shorea contorta) differing in wood service life and utilisation. Wood of $H$. plagata, the most durable species, contained the lowest concentrations of nitrogen and ligno-protein, the highest $\mathrm{C} / \mathrm{N}$ ratio and the lowest lignin concentration per dry mass but the highest lignin and extractive concentrations per wood density. FTIR spectroscopic studies of wood and isolated lignins of $D$. kerrii and $H$. plagata revealed differences compared to $P$. malaanoman and Shorea sp., which are species with short service life. Lignins of the Shorea/Parashorea species had a higher G/S ratio than those of H. plagata and D. kerrii. This was also evident from histochemical staining. Principle component analysis of FTIR spectra identified differences in both lignin composition and lignoprotein content as major source of variation.
\end{abstract}

\section{Introduction}

The large tree family of Dipterocarpaceae is not only a keystone ecological resource of wood in tropical Southeast Asia, but also comprises the most important tropical timbers for trading (Whitemore 1984). This is especially true for the Philippines

Electronic supplementary material The online version of this article (doi:10.1007/s00226-009-0281-2) contains supplementary material, which is available to authorized users.

R. Rana · R. Langenfeld-Heyser · A. Polle $(\bowtie)$

Forstbotanik und Baumphysiologie, Büsgen-Institut, Büsgenweg 2, 37077 Göttingen, Germany

e-mail: apolle@gwdg.de

R. Finkeldey

Forstgenetik und Forstpflanzenzüchtung, Büsgen-Institut, Büsgenweg 2, 37077 Göttingen, Germany 
where dipterocarps contribute $94 \%$ of the timber volume (Soerianegara and Lemmens 1994).

Timbers of dipterocarps have many different applications. For example, the socalled Apitong group of Philippine wood is composed of nine dominant tree species of the genus Dipterocarpus and contains the most common commercial structural timbers (Newman et al. 1996). The wood is hard and heavy and has been classified as general utility material. Dipterocarpus kerrii (trade name Minyak), a member of this group, has a density of $700-910 \mathrm{~kg} \mathrm{~m}^{-3}$ and is an excellent construction timber but requires protective treatments if used outdoors in the tropics (Newman et al. 1996).

The Yakal group comprises 12 species of the genera Hopea and Shorea. Woods of this group are used for high-grade construction works and other installations requiring high strength and durability. In this group, Hopea plagata (density: 800$1,200 \mathrm{~kg} \mathrm{~m}^{-3}$ ) has been reported to be very durable under weather-exposed conditions, including contact with the ground in wet tropics (Lomibao 1973; Newman et al. 1996).

The 'Philippine mahogany group' is composed of 7-9 traditional export species, which include common species of the genera Shorea, Parashorea, and Pentacme. This group ranks first as a source of $\log$ and lumber export comprising the bulk of lumber in the domestic market and veneer logs for the plywood mills. These timbers are used for furniture and cabinets because of their beautiful colour and grain; their wastes and residues are used for pulp and papermaking. This group has low to medium wood densities of $400-590 \mathrm{~kg} \mathrm{~m}^{-3}$ and contains species such as Parashorea malaanoman (trade names: Bagtikan, White Lauan), Shorea almon (trade names: Meranti or Red Mahogany) and Shorea contorta (synonym Pentacme contorta, trade name: White Lauan). P. malaanoman and S. almon can attain a service life of 2-4 years in exposed conditions, whereas the service life of $S$. contorta is only 1-2 years (Newman et al. 1996). The reasons for the differences in the durability of the dipterocarps in the Apitong, Yakal and Mahogany group are unknown.

Wood durability is provided by lignin and other extractives (Gierlinger et al. 2004a). However, accessibility of microorganisms due to structural differences in wood anatomy or the availability of potential nutrients such as protein may also be involved in affecting wood service life. Lignins are the major polyphenolic compounds in wood, constituting about $20-30 \%$ of the dry mass (Boerjan et al. 2003). The incorporation of lignins renders plant cell walls mechanically rigid, water repellent and chemically resistant, thereby determining tissue quality. Lignins constitute a major defence against pathogens, insects, predators, and UV-light (Polle et al. 1997; Whetten et al. 1998). Studies on lignin in tropical trees are very rare. The lignin content of some species has been reported to range from 29.4 to $40.5 \%$ (Fengel et al. 1983; Saka 2001; Pastore et al. 2004). The wood of Trema orientalis, a fast growing hardwood species in tropical countries, contains $45-50 \%$ of lignin (Jahan and Mun 2007). In another study on 36 Brazilian Amazon forest wood species, the range of lignin content was reported to be 26-37\% (Santana and Okino 2007). However, information on wood lignin and other wood constituents of commercially important dipterocarps is lacking. 
In the present study, wood and lignin of five important dipterocarp timber species native to the Philippines, D. kerrii, H. plagata, P. malaanoman, S. almon and $S$. contorta, was investigated which represent different classes of durability and utilisation purposes. Wood was obtained from a research plantation (Leyte, Philippines). To characterise lignification, cross sections of the five species were stained with Wiesner and Mäule reagents, respectively, to localise guaiacyl- and syringyl-lignins in cell walls. The lignin content was quantified by the Klason method. Klason lignins of the different species were characterised by FTIR spectroscopy and were compared with their respective wood spectra. To find out whether the lignin and wood differed in their composition, the FTIR spectra were subjected to principal component analysis and the major chemical constituents of the factor loadings contributing to spectral separation were identified. In addition, wood extractives, carbon, and nitrogen contents were measured.

\section{Materials and methods}

Field site and wood materials

Stem samples of five dipterocarp species [Dipterocarpus kerrii King Damar, Hopea plagata (Blanco) S. Vidal, Parashorea malaanoman (Blanco) Merr, Shorea almon Foxw and Shorea contorta Vidal] were collected after felling of 6-year-old trees grown in a plantation at the western foothills of Mt. Pangasugan, within the forest reserve of the Leyte State University Leyte (Philippines, $9^{\circ} 55^{\prime} \mathrm{N}-11^{\circ} 48^{\prime} \mathrm{N}$ and $\left.124^{\circ} 17^{\prime} \mathrm{E}-125^{\circ} 18^{\prime} \mathrm{E}\right)$. Only healthy trees with no apparent injury were used. Stem disks were excised from each tree at 1.3, 3 and $6 \mathrm{~m}$ above ground (except for $S$. almon, which did not reach heights above $6 \mathrm{~m}$ ) and were transported in sealed plastic bags. If not indicated otherwise, analyses were performed with material from stem disks taken at $1.3 \mathrm{~m}$. An additional disk was cut at $1.3 \mathrm{~m}$ height and stored in $70 \%$ ethanol for anatomical analyses. For each species, five individual trees were used for sampling. Wood densities were determined by the Archimedes' principle (Hacke et al. 2000).

\section{Lignin histochemistry}

Since the samples were very hard to section, especially those of $H$. plagata, a wood piece was cut in the middle between the disk centre and the boundary from ethanol preserved disks and softened as described by Wagenführ (1966). The wood pieces were boiled for about $90 \mathrm{~min}$ in $30 \%$ glycerine. Hopea plagata wood was boiled for $150 \mathrm{~min}$. After boiling, the samples were kept in a glycerol/ethanol/water solution (30\% ethanol, $30 \%$ glycerol, filled up to a final volume of $100 \mathrm{ml}$ with distilled water) for more than $30 \mathrm{~min}$ before sectioning. For anatomical studies, $30 \mu \mathrm{m}$ thick wood cross sections were cut with a sledge microtome (Reichert-Jung, Heidelberg, Germany).

Sections were directly mounted in phloroglucinol/HCl solution $(5.25 \mathrm{~g}$ phloroglucinol (1,3,5-trihydroxybenzol) dissolved in $350 \mathrm{ml} 95 \%$ ethanol and $175 \mathrm{ml}$ 
concentrated $\mathrm{HCl}$ (25\%) (adopted from Wiesner 1878 as modified by Eschrich 1976). Acidic phloroglucinol gives a red-pink product with cinnamyl aldehyde groups present in lignins (Vallet et al. 1996). Sections were treated with the Mäule reagent (Mäule 1901) (2\% w/v potassium permanganate, $5 \% \mathrm{HCl}$ and $1 \% \mathrm{NH}_{3}$ ) for the detection of the syringyl moieties (di-methoxylated residues) in lignin (Meshitsuka and Nakano 1978, 1979). Stained sections were mounted in 60\% glycerol for microscopy. Well-stained sections and a micrometer scale were photographed under a light microscope (Axioplan, Zeiss, Oberkochen, Germany) with a digital camera (Nikon CoolPix 990, Nikon, Tokyo, Japan). As the staining faded quickly, images were recorded within 20 min of reagent application.

Analyses of carbon, nitrogen, lignin and wood extractives

Lignin was determined as Klason lignin according to the method of Dence (1992). Isolated lignin and wood powder were used for carbon and nitrogen analysis. The material was weighed and filled into $\mathrm{Zn}$ capsules, which were then transferred for measurement into a CNS analyser (Vario L, Hanau, Germany). Wood was extracted with water and cyclohexane/ethanol in a Soxhlet apparatus and the extractive contents were determined gravimetrically according to TAPPI T204 om-88 (1987) as percentage of dry wood. Total extractives are indicated as the sum of organic and aqueous extractives.

FTIR-ATR spectroscopy of wood and Klason lignin and multivariate data analysis

Slices of the whole cross section excluding pith and outer wood were hackled with a gripper to small pieces and powdered in a ball mill (Retsch, MM 200 Hannover, Germany) for about $20 \mathrm{~min}$ at $60 \mu / \mathrm{min}$ and then with increasing the frequency to $90 \mu / \mathrm{min}$ for further $5 \mathrm{~min}$ to a fine powder. Klason lignin was also milled. FTIRATR spectra of milled wood and lignin powder were recorded with the FTIR spectrometer Equinox 55 (Bruker Optics, Ettlingen, Germany) combined with an ATR unit (DuraSamplIR, SensIR Europe, Warrington, England) at a resolution of $4 \mathrm{~cm}^{-1}$ for 32 scans in the range from 600 to $4,000 \mathrm{~cm}^{-1}$. The powdered samples were pressed against the diamond crystal of the ATR device. A pressure applicator with a torque knob ensured that the pressure applied was the same for all measurements. A background spectrum of the clear window was recorded prior to acquisition of sample spectra. The spectrum of the background was subtracted from spectrum of the sample before conversion into absorbance units. For each sample, five different sub-samples were analysed and averaged to give a mean spectrum per individual tree.

To compare FTIR spectra of wood and lignin and to determine peak heights, the spectra were baseline corrected and vector-normalised using software OPUS Version 6.5 (Bruker Optics, Ettlingen, Germany).

Lignin and wood spectra of individual trees were used for principal component analysis (PCA). For PCA of wood, the second derivatives of vector-normalised spectra were used in two specific regions (1,547-1,481 and 1,292-1,182 $\left.\mathrm{cm}^{-1}\right)$ and 
the factor loadings were calculated. For PCA of the FTIR spectra of Klason lignin the first derivative of vector-normalised spectra of the range of $1,800-1,200 \mathrm{~cm}^{-1}$ was used and factors loading were calculated. The highest seven peaks in the first, second and the third factor loadings were assigned. All theses operations were performed by using OPUS version 6.5 (Bruker Optics, Ettlingen, Germany).

Statistical analysis

Statistical tests were performed in SAS (version 9.13, SAS Institute Inc. 2004, Cary, NC, USA) using analysis of variance (ANOVA), followed by Duncan's multiple range test. Data were indicated as mean $\pm \mathrm{SD}$. Differences between mean were considered significant when the $P$ value of the ANOVA Duncan's multiple range test was less than 0.05 . Significant differences were marked by different letters.

\section{Results and discussion}

Lignin, carbon and nitrogen concentrations

The mean lignin concentration of four of the five dipterocarps used in this study was $23.4 \pm 0.5 \%$ (Table 1). Only, H. plagata contained significantly less lignin $(-16 \%)$ than the other species (Table 1). All lignin concentrations reported here are at the lower end of those reported in other investigations for tropical tree species (Fengel et al. 1983; Saka 2001; Pastore et al. 2004; Nuopponen et al. 2006; Jahan and Mun 2007; Santana and Okino 2007). The low lignin concentration of H. plagata was surprising since this species is reported to be among the most durable dipterocarps (Newman et al. 1996) pointing to other factors as determinants of durability.

Durability in tropical hardwoods is affected by the combination of wood density and the content and composition of lignin and extractives (Onuorach 2000; Nuopponen et al. 2006). It must, therefore, be considered that the five species of our study differ in their contents of extractives and wood densities. H. plagata contained the lowest concentration of water-soluble and the highest of organic extractives (Table 1). However, high concentrations of both, organic and water-soluble extractives were present in $P$. malaanoman and $S$. almon (Table 1), which are species with low wood durability. This suggests that the concentrations of lignin and wood extractives are insufficient to explain differences in durability.

Differences in wood densities are evident from Fig. 1. The cell walls of the fibres of $D$. kerrii and $H$. plagata wood were very thick, almost without any lumen (Fig. 1a, b, f, g), whereas those of P. malaanoman, S. almon and S. contorta were much thinner (Fig. 1c-e, h-j). This qualitative impression was supported by measurements of wood densities: $H$. plagata $\left(0.97 \mathrm{~g} \mathrm{~cm}^{-3}\right)>D$. kerrii $\left(0.70 \mathrm{~g} \mathrm{~cm}^{-3}\right)>P$. malaanoman $\left(0.45 \mathrm{~g} \mathrm{~cm}^{-3}\right)>S$. contorta $\left(0.40 \mathrm{~g} \mathrm{~cm}^{-3}\right)>$ $S$. almon $\left(0.35 \mathrm{~g} \mathrm{~cm}^{-3}\right)$ and confirms data reported by Newman et al. (1996) for the wood densities of these five species and those found in the wood density database (http://www.worldagroforestrycentre.org/sea/Products/AFDbases/WD/). Using our measured data, lignin concentrations per wood volume were calculated and the 


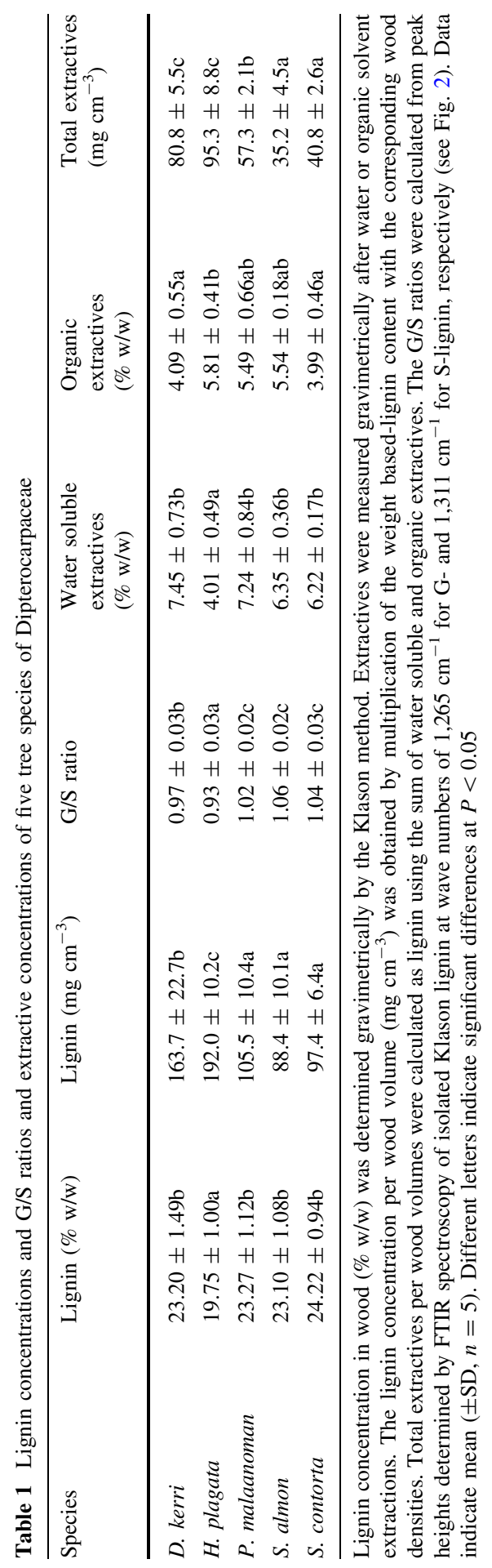



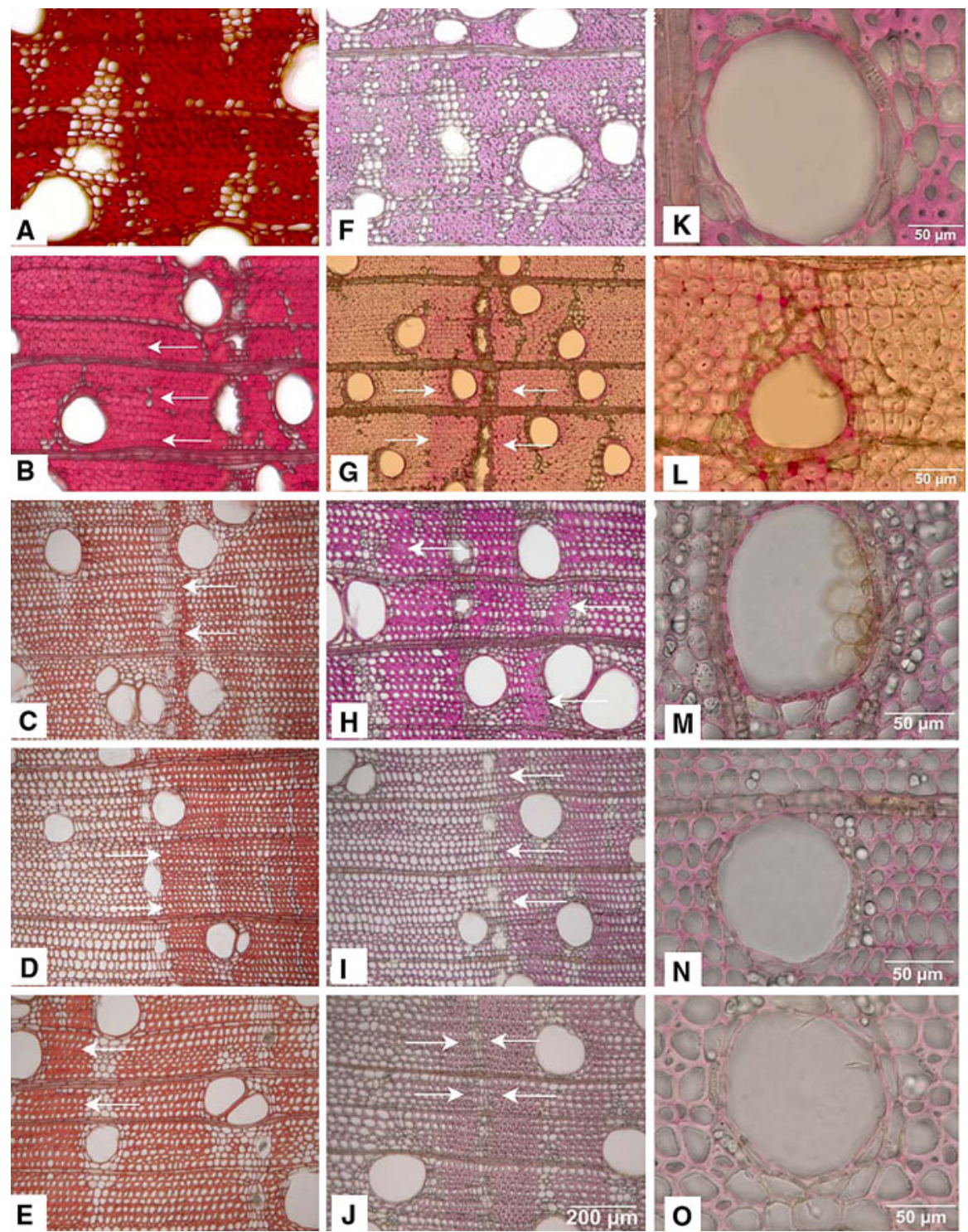

Fig. 1 Typical cross sections of wood of five Dipterocarpaceae: D. kerrii (a, f, k), H. plagata (b, g, l), P. malaanoman $(\mathbf{c}, \mathbf{h}, \mathbf{m}), S$. almon $(\mathbf{d}, \mathbf{i}, \mathbf{n})$ and $S$. contorta $(\mathbf{e}, \mathbf{j}, \mathbf{o})$ after Mäule (a-e) and phloroglucinol/ $\mathrm{HCl}$ staining $(\mathbf{f}-\mathbf{j})$. The scale bar in $\mathbf{j}$ refers to all figures from $\mathbf{a}-\mathbf{j}$. The arrows indicate the zones where fibre tracheids have very thick walls. Details of vessels after phloroglucinol/ $\mathrm{HCl}$ staining are shown in k-o. Sections were $30 \mu \mathrm{m}$ thick

highest values in $H$. plagata and the lowest in the Shorea and Parashorea species were found (Table 1). D. kerrii took an intermediate position (Table 1). This order reflects that of the durability and service life of these timbers. Similar results were obtained for wood extractives, where $H$. plagata and D. kerrii formed the group 
with the highest volume-based contents and the Shorea species the group with the lowest contents (Table 1). P. malaanoman took an intermediate position. A close correlation between wood extractive and resistance against basidiomycete-caused decay was found in larch (Windeisen et al. 2002). However, in nature many other pathogens or wood-inhabiting insects may cause wood degradation.

As in other tree species (Fengel and Wegener 2003), N concentrations in wood of the five species were low; the lowest concentrations were present in $\mathrm{H}$. plagata (Table 2). A significant fraction of the wood nitrogen was present in the isolated lignin (Table 2). The concentrations were in the same order of magnitude as those previously reported in lignins of temperate tree species (Fagus sylvatica, Dyckmans et al. 2002, Abies alba, Pinus insignis, Neus Anglès et al. 2003). Previous studies have suggested that this nitrogen fraction is mainly due to proteins bound to lignin, forming so-called ligno-proteins (Brinkmann et al. 2002). Comparing wood and lignin nitrogen concentration, it was inferred that $S$. almon had the highest fraction of lignin-bound nitrogen (48\% of total wood-N), H. plagata the lowest (30\%) and the other species took intermediate positions (P. malaanoman 33\%, D. kerrii 37\%, and $S$. contorta $42 \%$ ). Ligno-proteins are less available for microbial decay than the soluble nitrogen fraction of wood (Dyckmans et al. 2002) and therefore, the allocation of nitrogen between free and bound pools may be important for wood durability.

A further important indicator for the degradability of wood is the $\mathrm{C} / \mathrm{N}$ ratio (Enriquez et al. 1993). D. kerrii had the lowest $\mathrm{C} / \mathrm{N}$ ratio in both wood and lignin among the five dipterocarps tested (Table 2). This was caused by higher nitrogen concentrations in these fractions than in those of the other species. Since the trees were all grown together in the same plantation experiencing similar edaphic and climatic conditions, the differences found here reflect species-specific traits and not responses to differences in environmental conditions. Therefore, it was concluded that $D$. kerrii has a higher nitrogen requirement for wood formation than the other species. Since nitrogen is an important nutrient resource for microbes, elevated wood protein concentrations compared to those of the other species may be among the reasons that $D$. kerri unlike $H$. plagata cannot be used for outdoor applications despite its dense wood with relatively high lignin volume concentrations (Table 1).

Histochemical wood analyses

The localisation and composition of lignin are important wood properties because guaiacyl (G-)lignins are more strongly cross-linked and therefore, more resistant to chemical degradation than lignins with a high syringyl content (S-lignin) (Nuopponen et al. 2006). Higuchi (1990) has reported that the characteristics of the lignin macromolecule can prevent the hydrolysis of cellulose "in situ" by various organisms. To obtain an indication for differences in lignin localisation and composition, cross sections were stained with Mäule or Wiesner reagent, respectively. Cell walls containing only syringyl units or both guaiacyl and syringyl units turn predominantly reddish purple, whereas cell walls containing guaiacyl units remain yellowish or brownish in colour after staining with Mäule reagent (Watanabe et al. 1997, 2004). In D. kerrii (Fig. 1a) and H. plagata (Fig. 1b), the Mäule reaction revealed dark reddish orange and vivid purplish red colours, 


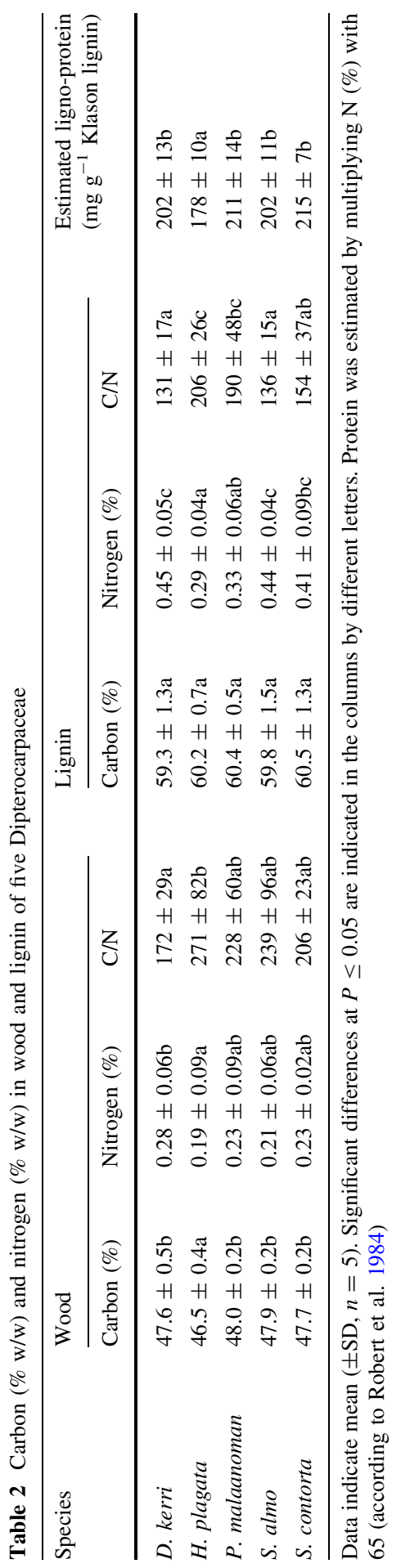


respectively. P. malaanoman (Fig. 1c) and the two Shorea species, S. almon and S. contorta (Figs. 1d, e) displayed strongly red colours; the staining intensity in the latter three species was similar. Staining revealed the presence of more or less dense wood "zones" in all species except $D$. kerrii (Fig. 1a-e). These zones were caused by thick and thin-walled fibre tracheids, which were less prominent in $H$. plagata (Fig. 1b) than the other species.

Coniferyl alcohol is usually also an abundant compound in angiosperm wood. During lignification, its precursor, coniferyl aldehyde, is incorporated into lignin in small amounts. Coniferyl aldehydes produce a strong red colouration with phloroglucinol/HCl (Pomar et al. 2002). Both D. kerrii (Fig. 1f) and H. plagata (Fig. 1g) expressed only a moderate purplish-pink colour with the Wiesner stain. The most intense colouration with the Wiesner stain was found in P. malaanoman (Fig. 1h). These observations point to differences in the G/S ratios of the dipterocarps species. However, the qualitative data do not suggest a low S-content as, e.g., found in Triplochiton scleroxylon (Faix et al. 1991).

Further differences were observed between the lignification of the vessel walls. In H. plagata (Fig. 11) and P. malaanoman (Fig. 1m) vessel walls were stained more strongly with the Wiesner reagent than the surrounding area, probably indicating higher intensity of G-lignin and, thus, higher rigidity of the vessel walls of these species compared to those of D. kerrii (Fig. 1k), S. contorta and S. almon (Fig. 1n, o).

The chemical finger print of wood and of lignin

FTIR analysis of dipterocarp wood showed prominent peaks in the finger print regions of $1,800-600 \mathrm{~cm}^{-1}$ (Fig. 2a). The peaks were numbered and assigned to chemical compounds according to published literature (Supplementary Table S1). Most of the observed peaks of wood represent major cell wall components such as cellulose $\left(1,154,898 \mathrm{~cm}^{-1}\right.$ corresponding to peak numbers 13 and 19), hemicelluloses $\left(1,738,1,024,1,057,1,090 \mathrm{~cm}^{-1}\right.$ [peak numbers $\left.\left.1,17,16,15\right]\right)$ and lignin $\left(1,596,1,505,1,270 \mathrm{~cm}^{-1}\right.$, [peak numbers $4,5,10$ ], Table S1). Although the wood spectra of the five different species were very similar, closer inspection revealed some differences in $D$. kerrii and H. plagata spectra (Fig. 2a) compared to those of the other three species. Peak 3 arising at $1,626 \mathrm{~cm}^{-1}$ due to stretching vibration of $\mathrm{C}=\mathrm{O}$ (Parker 1983) and peak 21 at $781 \mathrm{~cm}^{-1}$ (unknown compounds) were present only in H. plagata. The guaiacyl peaks (peak 10) in D. kerrii and H. plagata were not as prominent as in the other three species (Fig. 2a). Peak 9 at 1,330 $(1,320)$ $\mathrm{cm}^{-1}$, which indicates syringyl ring breathing with CO stretching (Hergert 1971; Fengel and Wegener 2003), was more pronounced in H. plagata than in the other species (Fig. 2a).

In addition to wood, Klason lignin of the five dipterocarps was also analysed by FTIR spectroscopy (Fig. 2b). As expected, the absorbance in the region from 1,200 to $900 \mathrm{~cm}^{-1}$, which is the polysaccharide region (Faix et al. 1991; Naumann et al. 1991), was strongly diminished in lignin compared to wood spectra (Fig. 2a, b). The wood bands 3 and 21 characteristic of $H$. plagata, disappeared in the lignin spectrum of this species (Fig. 2b). 

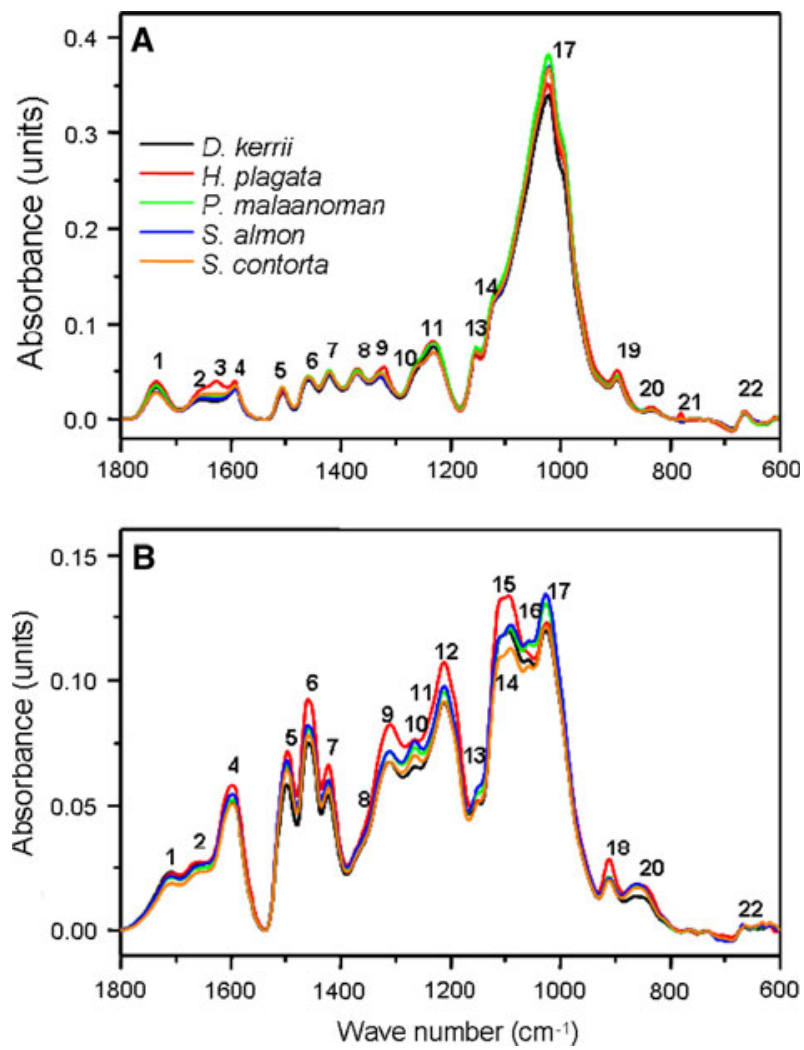

Fig. 2 Mean FTIR spectra of wood (a) and lignin (b) of five different species of dipterocarps from the same site in the wave number range from 1,800 to $600 \mathrm{~cm}^{-1}$. Each spectrum is a mean of spectra from five individual trees sampled from $D$. kerrii, $H$. plagata, P. malaanoman, S. almon, S. contorta, respectively. The different numbers refer to peaks described in the text. A full list is given under electronic supplementary materials

Peak 9 at $1,320-1,330 \mathrm{~cm}^{-1}$ in wood spectra arising due to $\mathrm{CO}$ stretch and syringyl ring breathing was shifted in lignin spectra to position $1,311 \mathrm{~cm}^{-1}$ (Fig. 2a, b). Faix et al. (1994) found a similar shift in lignin of Triplochiton scleroxylon lignin, which is a diffuse porous tropical tree species. The shifting of peak 1 in the lignin compared with wood spectra (Fig. 2) is probably an indication that the dipterocarps contained low amounts of phenolic hydroxyl groups (Faix 1987; Wegener and Strobel 1991; Faix et al. 1992). Similarly, the G-lignin peak (number 10) at $1,270 \mathrm{~cm}^{-1}$ in the wood spectra was shifted to $1,265 \mathrm{~cm}^{-1}$ in the lignin spectra. This shift might have been caused by inductive effects of substituents (e.g., $\mathrm{H}_{3} \mathrm{CO}$ ) in the aromatic ring system of lignin (Pastusiak 2003).

In both wood $\left(1,270 \mathrm{~cm}^{-1}\right)$ and lignin $\left(1,265 \mathrm{~cm}^{-1}\right)$ spectra, the guaiacyl peaks (band 10) showed lower intensity in D. kerrii than the other species (Fig. 2a, b). When the guaiacyl to syringyl ratios were calculated for $1,265 \mathrm{~cm}^{-1} / 1,311 \mathrm{~cm}^{-1}$, the G/S ratios for P. malaanoman and the two Shorea species were higher than those of $D$. kerrii and H. plagata (Table 1). The G/S ratios corroborate the histochemical 
analysis (Fig 1 ) by showing that $D$. kerrii and $H$. plagata lignins are composed of relatively less G- than $\mathrm{S}$-moieties (Table 1). This observation for the most durable woods was unexpected because it was assumed that lower G/S ratios would decrease cross-linking and thus, contribute to decreasing wood bio-resistance. However, the distinct Klason lignin spectral patterns of $H$. plagata and D. kerrii clearly indicated the presence of additional components, which might contribute to wood resistance (Fig 2a).

Principle component analysis of the FTIR spectra of wood and lignin

To obtain more information on species-related differences in wood or lignin spectra, respectively, PCA analysis was conducted. Figure 3a shows a PCA projection calculated from the spectral data sets of wood of each individual tree. The plot has been constructed by three-dimensional projection of Eigenvectors (factor spectra) 1, 2 and 3 so that the intrinsic group or class structure of the whole data set can be inspected. Each point in the map represents a spectrum; all three factorial coordinates (factor loadings) were used for data representation (Fig. 3a). The best model with three principal components was found by trial and error when using second derivation, vector normalised spectra in the range of $1,547-1,481 \mathrm{~cm}^{-1}$ and 1,292-1,182 $\mathrm{cm}^{-1}$ as input data (factor loadings see supplementary Fig. S1). The principle components from $D$. kerrii and $H$. plagata formed two distinct groups which were separated from those formed by $S$. almon, $S$. contorta, and P. malaanoman (Fig. 3a). The latter three species were not separated by this analysis. Wood from three different heights was also analysed in this way. However, no significant effects were found (data not shown).

PCA with the lignin spectra also separated $D$. kerrii and $H$. plagata from a group formed by the other three species (Fig. 3b). In this case, the best model with three principal components was obtained when using the first derivation of vector normalised spectra in the whole range of $1,800-1,200 \mathrm{~cm}^{-1}$ as input data (factor loadings see supplementary Fig. S2). The model was not improved by deletion of wave number ranges in which the spectra were overlapping. This result indicates that the chemical composition of the lignin fractions from P. malaanoman, $S$. almon, and S. contorta did not differ, whereas $D$. kerrii and $H$. plagata lignins can be distinguished from the former group and also among each other.

To investigate the source of variation, factor loadings for the principle components of wood and lignin were analysed. Using wood spectra, the factor loading of the first factor had an Eigenvalue of 4.937, which explains $98.7 \%$ of the variation. The second and third factor explained 1.06 and $0.0016 \%$ of the variation, respectively. To identify the major factors contributing to the separation of spectra of $H$. plagata and D. kerrii from the Parashorea/Shorea group, the seven major peaks of the first and second factor loadings were assigned to their chemical constituents, respectively (Table 3). In our study, the third factor loading was not considered because it accounted for a very low percentage of variation. The tentative band assignments of the factor loadings indicated that amide bands (peak 1 and 8, supplementary fig. S1) were important for both factors and that lignin peaks at 1,505 and $1,510 \mathrm{~cm}^{-1}$ were important for the first and second factor, respectively 

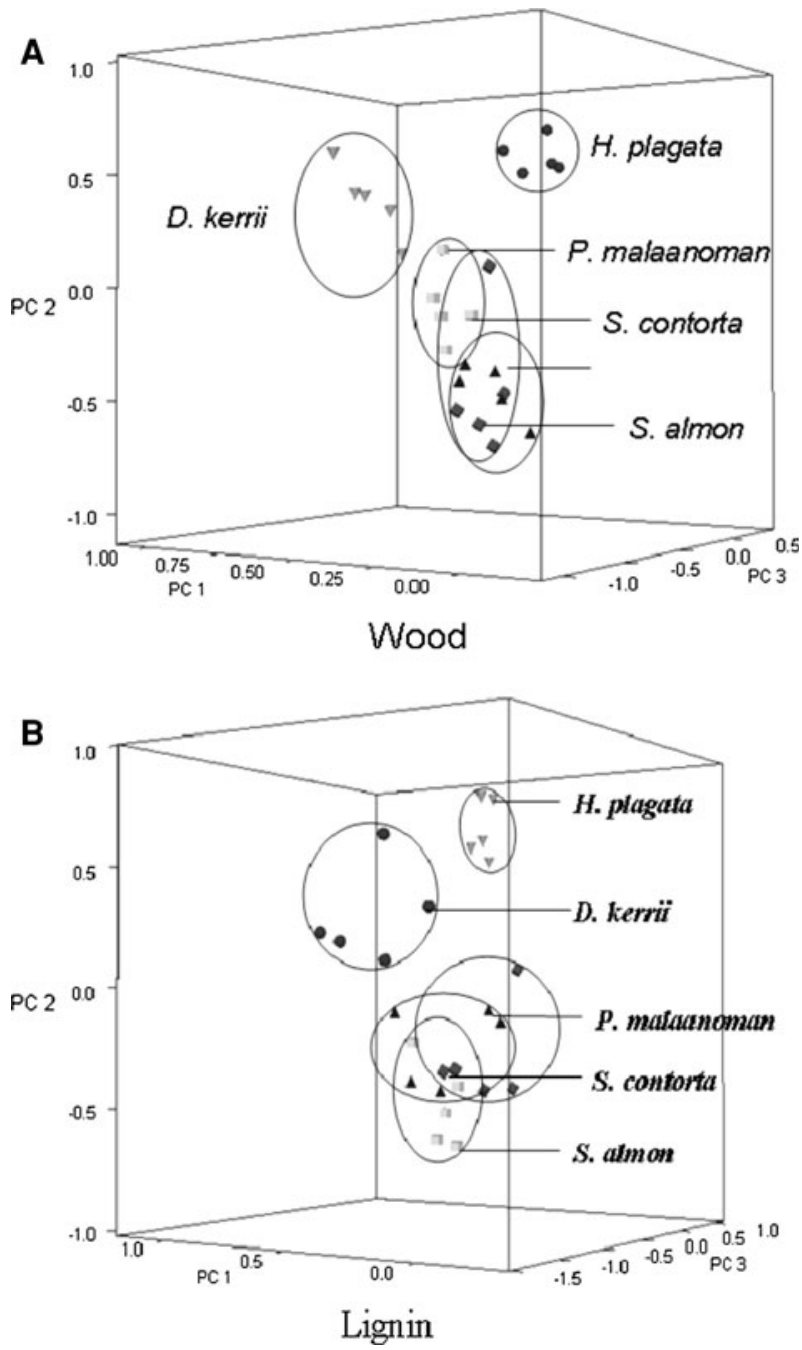

Fig. 3 Principle component analysis of wood (a) and Klason lignin (b) for five Dipterocarpaceae. PCA was conducted with five FTIR spectra per species. For projection of data, the factorial coordinates (factor loadings) PC1, PC2 and PC3 were used. For the wood (a), PC1, PC2, PC3 were obtained from second derivative of vector-normalised spectra in two spectral ranges $\left(1,547-1,481 \mathrm{~cm}^{-1}\right.$ and $1,292-$ $1,182 \mathrm{~cm}^{-1}$ ). For lignin (b), PC1, PC2, and PC3 were obtained from first derivative of vectornormalised data in the spectral range $1,800-1,200 \mathrm{~cm}^{-1}$

(Table 3). The band at $1,270 \mathrm{~cm}^{-1}$ which has been assigned to guaiacyl lignin (Fengel and Wegener 2003) was also present in both factors. Besides, stretching vibrations of various compounds (mainly carbon in combination with other compounds) were found in both the factor loadings (Table 3). These data indicate that in addition to some other compounds, especially amides and lignins contributed to the variations between the species. This result supports our chemical analysis, 
Table 3 Band assignments of the first and second factor loadings obtained by principal component analysis of wood FTIR spectra of five dipterocarps

\begin{tabular}{|c|c|c|c|}
\hline $\begin{array}{l}\text { Wave } \\
\text { number } \\
\left(\mathrm{cm}^{-1}\right)\end{array}$ & Band origin & Short comments & References \\
\hline $1,524(1)$ & $\mathrm{N}-\mathrm{H}$ deformation & $\begin{array}{l}\text { Secondary amide (upward } \\
\text { direction) }\end{array}$ & Parker (1983) \\
\hline $1,505(2)$ & Same as peak 1,510 & Downward direction & Faix (1991) \\
\hline $1,286(3)$ & Amide III & Protein (upward direction) & $\begin{array}{l}\text { Naumann et al. } \\
\text { (1991) }\end{array}$ \\
\hline $1,270(4)$ & Guaiacyl ring breathing & $\begin{array}{l}\text { Present in both factors, down- } \\
\text { and upward direction in first } \\
\text { and second factor loading } \\
\text { respectively }\end{array}$ & $\begin{array}{l}\text { Fengel and } \\
\text { Wegener (2003) }\end{array}$ \\
\hline $1,251(5)$ & $\mathrm{C}-\mathrm{O}$ stretching & $\begin{array}{l}\mathrm{CH}_{3} \mathrm{COOR} \text {, acetic ester (upward } \\
\text { direction) }\end{array}$ & Parker (1983) \\
\hline $1,227(6)$ & $\begin{array}{l}\mathrm{C}-\mathrm{C} \text { plus } \mathrm{C}-\mathrm{O} \text { plus } \mathrm{C}=\mathrm{O} \\
\text { stretch; } \\
\mathrm{G} \text { condensed }>\mathrm{G} \text { etherified }\end{array}$ & Downward direction & Faix (1991) \\
\hline $1,197(7)$ & $\mathrm{C}-\mathrm{O}-\mathrm{C}, \mathrm{C}-\mathrm{O}$ & $\begin{array}{l}\text { Dominated by ring vibration } \\
\text { of carbohydrates }\end{array}$ & $\begin{array}{l}\text { Naumann et al. } \\
\text { (1991) }\end{array}$ \\
\hline $1,522(8)$ & $\mathrm{N}-\mathrm{H}$ deformation & $\begin{array}{l}\text { Secondary amide (downward } \\
\text { direction) }\end{array}$ & Parker (1983) \\
\hline $1,510(9)$ & $\begin{array}{l}\text { Aromatic skeletal vibration } \\
\text { plus } \mathrm{C}=\mathrm{O} \text { stretch; } \mathrm{S}>\mathrm{G} \text {; } \\
\mathrm{G} \text { condensed }>\mathrm{G} \text { etherified }\end{array}$ & Upward direction & $\begin{array}{l}\text { Faix (1991), } \\
\text { Evans (1991) }\end{array}$ \\
\hline $1,496(10)$ & $\mathrm{C}=\mathrm{S}$ stretching & $-\mathrm{N}-\mathrm{C}=\mathrm{S}$ (downward direction) & Parker (1983) \\
\hline $1,485(11)$ & $\mathrm{C}=\mathrm{S}$ stretching & $-\mathrm{N}-\mathrm{C}=\mathrm{S}$ (upward direction) & Parker (1983) \\
\hline $1,270(12)$ & Guaiacyl ring breathing & $\begin{array}{l}\text { Present in both factors. } \\
\text { Downward and up ward } \\
\text { direction in first and second } \\
\text { factor loading }\end{array}$ & $\begin{array}{l}\text { Fengel and } \\
\text { Wegener (2003) }\end{array}$ \\
\hline $1,238(13)$ & $\mathrm{C}-\mathrm{O}$ stretching & Downward direction & Parker (1983) \\
\hline $1,208(14)$ & $\mathrm{C}-\mathrm{N}$ stretching vibration & $\begin{array}{l}\text { Aliphatic amine (upwards } \\
\text { direction) }\end{array}$ & Parker (1983) \\
\hline
\end{tabular}

The first seven peaks are assigned to each factor loading. The numbers in parenthesis indicate their positions in supplementary Fig. S1 A (peak 1-7, first factor) and Fig. S1 B (peak 8-14, second factor), respectively. Peak $1,268 \mathrm{~cm}^{-1}$ is present in both factors

showing significant differences in lignin and nitrogen concentrations between H. plagata, D. kerrii, and the Parashorea/Shorea species (Tables 1, 2).

Analysis of factor loadings of the PCA of lignin spectra revealed similar results to wood. The first, second and the third factor had Eigenvalues of 4.983, 0.013, and, 0.002 , respectively, and explained 99.71, 0.26, and $0.05 \%$ of the variances, respectively (Supplementary Fig S2). Band assignments of the seven highest peaks of the factor loadings showed aromatic ring vibrations in all three-factor loadings in addition to several stretching compounds (Table 4). It is notable that amides were also identified to contribute to the variation (1st and 3rd factor, Table 4). This 
Table 4 Band assignments of the first (PC1), second (PC2) and third (PC3) factor loadings obtained by principal component analysis of lignin FTIR spectra of five dipterocarps

\begin{tabular}{|c|c|c|c|}
\hline $\begin{array}{l}\text { Wave number } \\
\left(\mathrm{cm}^{-1}\right)\end{array}$ & Factor & Band origin & References \\
\hline $1,515(1)$ & 1 & Aromatic skeletal vibration & $\begin{array}{l}\text { Hergert (1971), Fengel } \\
\text { and Wegener (2003) }\end{array}$ \\
\hline $1,444(2)$ & 1 & $\begin{array}{l}\text { Stretching vibration of } \mathrm{C}-\mathrm{O} \text {, } \\
-\mathrm{COO}^{-}, \text {carboxylate }\end{array}$ & Parker (1983) \\
\hline $1,470(3)$ & 1 & $\begin{array}{l}\mathrm{C}-\mathrm{H} \text { deformations; asym. in } \\
-\mathrm{CH}_{3} \text { and }-\mathrm{CH}_{2}-\end{array}$ & $\begin{array}{l}\text { Faix (1991), Fengel and } \\
\text { Wegener (2003) }\end{array}$ \\
\hline $1,580(4)$ & 1 & $\begin{array}{l}\text { Interaction effects of } \mathrm{C}=\mathrm{N} \\
\quad \text { (plus } \mathrm{C}=\mathrm{C} \text { ) }\end{array}$ & Parker (1983) \\
\hline $1,411(5)$ & 1 & $\begin{array}{l}\text { Stretching vibration of } \mathrm{C}-\mathrm{O} \text {, } \\
-\mathrm{COO}^{-}, \text {carboxylate }\end{array}$ & Parker (1983) \\
\hline $1,488(6)$ & 1 & Stretching vibration of $\mathrm{C}=\mathrm{S}$ & Parker (1983) \\
\hline $1,338(7)$ & 1 & Hydroxyl compounds & Hergert (1971) \\
\hline $1,251(1)$ & 2 & $\begin{array}{l}\mathrm{C}-\mathrm{O} \text { stretching }\left(\mathrm{CH}_{3} \mathrm{COOR} \text {, acetic }\right. \\
\text { ester (upward direction) }\end{array}$ & Parker (1983) \\
\hline $1,515(2)$ & 2 & Aromatic ring vibrations & $\begin{array}{l}\text { Hergert (1971), Fengel } \\
\text { and Wegener (2003) }\end{array}$ \\
\hline $1,282(3)$ & 2 & Stretching vibration of $\mathrm{C}-\mathrm{O}$ & Parker (1983) \\
\hline $1,500(4)$ & 2 & Aromatic skeletal vibration & Faix (1991) \\
\hline $1,474(5)$ & 2 & Stretching vibration of $\mathrm{C}=\mathrm{S}$ & Parker (1983) \\
\hline $1,450(6)$ & 2 & $\begin{array}{l}\text { Stretching vibration of } \mathrm{C}-\mathrm{O} \text {, } \\
-\mathrm{COO}^{-}, \text {carboxylate }\end{array}$ & Parker (1983) \\
\hline $1,351(7)$ & 2 & Hydroxyl compounds & Hergert (1971) \\
\hline $1,500(1)$ & 3 & Aromatic skeletal vibration & Faix (1991) \\
\hline $1,474(2)$ & 3 & Stretching vibration of $\mathrm{C}=\mathrm{S}$ & Parker (1983) \\
\hline $1,587(3)$ & 3 & Asymmetric deformation of $\mathrm{NH}_{3}{ }^{+}$ & Parker (1983) \\
\hline $1,748(4)$ & 3 & Hydroxyl groups & Hergert (1971) \\
\hline $1,400(5)$ & 3 & $\mathrm{C}-\mathrm{O}$ stretching $(\mathrm{sym})$ of $\mathrm{COO}^{-}$ & Naumann et al. (1991) \\
\hline $1,732(6)$ & 3 & $\begin{array}{l}\mathrm{C}=\mathrm{O} \text { stretch in unconjugated ketones, } \\
\text { in carbonyl and ester groups } \\
\text { (frequently of carbohydrate origin) }\end{array}$ & $\begin{array}{l}\text { Faix (1991), Pandey and } \\
\text { Pitman (2003) }\end{array}$ \\
\hline $1,244(7)$ & 3 & $\begin{array}{l}\mathrm{C}=\mathrm{O} \text { and } \mathrm{C}-\mathrm{O} \text { vibrations of the acetyl } \\
\text { groups in hardwood xylan }\end{array}$ & Harrington et al. (1964) \\
\hline
\end{tabular}

The seven highest peaks are indicated for each factor loading. The numbers in parenthesis indicate the position according to peak height as shown in supplementary Fig. S2A, B, C

suggests that the measured differences in ligno-protein content and in the composition of aromatic compounds were important to distinguish lignins from $H$. plagata and $D$. kerrii from those of the other three species.

In previous studies, FTIR spectroscopy in combination with PCA has been applied to discriminate some woody species (Brunner et al. 1996; Gierlinger et al. 2004b) and to distinguish lignins (Faix 1991; Cortrim et al. 1999). However, in our study species separation was only possible for $H$. plagata and $D$. kerrii from those of the Shorea/ 
Parashorea group. For wood, focus was put on particular spectral regions $(1,547-$ 1,481 and $1,292-1,182 \mathrm{~cm}^{-1}$ ), where the differences were most pronounced to obtain reasonable species separation. In contrast, the same separation of lignins was easily achieved by using the whole finger print region suggesting that the differences in lignin compositions were a major source variation in our samples and might have at least partly been masked by other organic compounds present in wood.

\section{Conclusion}

In the present study, some wood properties of five important tropical timber wood species of the Dipterocarpaceae, which differ in durability, were characterised. Our analysis shows that these differences were not related to differences in the lignin or extractive concentrations (per weight) but to wood densities and lignin and extractive concentrations per volume. FTIR spectra of wood showed that the five species contained typical G/S lignins but the G/S ratio was not related to durability. PCA analysis of the FTIR spectra indicated that wood and lignin properties of $S$. almon, $S$. contorta, and $P$. malaanoman, i.e., the species with short service life in exposed conditions, were indistinguishable, whereas those of $H$. plagata and D. kerrii were clearly separated because of differences in lignin content, composition and amide compounds. The most resistant species, H. plagata, contained the highest $\mathrm{C} / \mathrm{N}$-ratio and displayed bands in wood FTIR spectra, which were not present in the other four species.

All five species studied here are endangered by over-utilisation of the tropical forests (Langenberger 2006; Langenberger et al. 2006). Sustainable utilisation and management strategies must therefore be developed. Our study characterised some wood traits of economic importance in these species and may also have ecological implications. The finding that $H$. plagata has low nitrogen content in combination with high wood and lignin densities suggests that this species may be better adapted to soils with low nutrients and drought periods than the other species investigated here.

Acknowledgments We are grateful to the DAAD (Deutscher Akademischer Austauschdienst) for funding a PhD scholarship to Rumana Rana and to G. Langer-Kettner for excellent technical assistance.

Open Access This article is distributed under the terms of the Creative Commons Attribution Noncommercial License which permits any noncommercial use, distribution, and reproduction in any medium, provided the original author(s) and source are credited.

\section{References}

Boerjan W, Ralph J, Baucher M (2003) Lignin biosynthesis. Annu Rev Plant Biol 54:519-546

Brinkmann K, Blaschke L, Polle A (2002) Comparison of different methods for lignin determination as a basis for calibration of near infrared spectroscopy and implications of ligno-proteins. J Chem Ecol 28:2483-2501

Brunner M, Eugster E, Trenka E, Strotz LB (1996) FT-NIR spectroscopy and wood identification. Holzforsch 50:130-134 
Cortrim AR, Ferraz A, Gongalves AR, Silva FT, Bruns RE (1999) Identifying the origin of lignins and monitoring their structural changes by means of FTIR-PCA and SIMCA. Bioresource Technol 68:29-34

Dence CW (1992) Lignin determination. In: Stephen YL (ed) Methods in lignin chemistry. Springler, Berlin, pp 33-61

Dyckmans J, Flessa H, Brinkmann K, Mai C, Polle A (2002) Carbon and nitrogen dynamics in the structural biomass of beech (Fagus sylvatica, L.) during the growth phase. Plant Cell Environ 25:469-478

Enriquez S, Duarte CM, Sand-Jensen K (1993) Patterns in decomposition rates among photosynthetic organisms: the importance of detritus C:N:P content. Oecol 94:457-471

Eschrich W (1976) Strasburger's kleines Botanisches Praktikum für Anfänger. Gustav Fischer Verlag, Stuttgart, p 193

Evans PA (1991) Differentiating "hard" from "soft" woods using Fourier transform infrared and Fourier transform Raman spectroscopy. Spectrochim Acta 47A:1441-1447

Faix O (1987) Quantitative FTIR-spektroskopische Untersuchungen an Ligninen und Ligninmodellsubstanzen. Habilitationsschrift, Fachbereich Biologie Universität, Hamburg

Faix O (1991) Classification of lignins from different botanical origins by FTIR spectroscopy. Holzforsch 45:21-27

Faix O, Bremer J, Schmidt O, Stevanovic J (1991) Monitoring of chemical changes in white-rot degraded beech wood by pyrolysis-gas chromatography and Fourier transform infrared spectroscopy. J Anal Appl Pyrolysis 21:147-162

Faix O, Grünwald C, Beinhoff O (1992) Determination of phenolic hydroxyl group content of milled wood lignins (MWL's) from different botanical origins using selective aminolysis, FTIR, ${ }^{1} \mathrm{H}-\mathrm{NMR}$, and UV spectroscopy. Holzforsch 46:425-432

Faix O, Stevanovic-Janezic T, Lundquist K (1994) The lignin of the diffuse porous angiosperm tree Triplochyton scleroxylon K. Schum with low syringyl content. J Wood Chem Technol 14:263-273

Fengel D, Wegener G (2003) Wood, chemistry and ultrastructure and reactions. Kassel Verlag, Ramagen, pp 132-164

Fengel D, Greune A, Wegener G (1983) Charakterisierung von drei Tropenholzligninen. Holzforsch 37:121-124

Gierlinger N, Jacques D, Schwanninger M, Wimmer RP, Pâques LE (2004a) Heartwood extractives and lignin content of different larch species (Larix sp.) and relationship to brown-rot decay-resistance. Trees 18:230-236

Gierlinger N, Schwanninger M, Wimmer J (2004b) Characteristics and classification of Fourier-transform near infrared spectra of heartwood of different larch species (Larix sp.). J Near Inf Spec 12:113-119

Hacke U, Sperry G, Pittermann JS (2000) Drought experience and cavitation resistance in six shrubs from the Great Basin, Utah. Basic Appl Ecol 1:31-41

Harrington KJ, Higgins HG, Michell AJ (1964) Infrared spectra of Eucalyptus regnans F. Muell. and Pinus radiata D. Don. Holzforsch 18:108-113

Hergert HL (1971) Infrared spectra. In: Sarkanen KV, Ludwig CH (eds) Lignins: Occurrence, formation, structure and reactions. Wiley, New York, pp 267-297

Higuchi T (1990) Lignin biochemistry: biosynthesis and biodegradation. Wood Sci Technol 24:23-26

Jahan MS, Mun SP (2007) Characteristics of dioxane lignins isolated at different ages of natalia wood (Trema orientalis). J Wood Chem Technol 27:83-98

Langenberger G (2006) Habitat distribution of dipterocarp species in the Leyte Cordillera: an indicator for species-site suitability in local reforestation programme. Ann For Sci 63:149-156

Langenberger G, Martin K, Sauerborn J (2006) Vascular plant species inventory of a Philippine lowland rain forest and its conservation value. Biodiv Conserv 15:1271-1301

Lomibao BA (1973) Guide to the identification of the woods of Philippine Dipterocarpaceae. Magazine for Forest Products Research and Industries Development (FORPRIDE digest) 2:26-34

Mäule C (1901) Das Verhalten verholzter Membranen gegen Kaliumpermanganat, eine Holzreaktion neuer Art. Beiträge zur wissenschaftlichen Botanik 4:166-185

Meshitsuka G, Nakano J (1978) Studies on the mechanism of lignin colour reaction (XII). Mäule colour reaction (8). Mokuzai Gakkaishi 24:563-568

Meshitsuka G, Nakano J (1979) Studies on the mechanism of lignin colour reaction (XIII). Mäule colour reaction (9). Mokuzai Gakkaishi 25:588-594 
Naumann D, Labischinski H, Giesbrecht P (1991) The characterization of microorganisms by Fourier transform infrared spectroscopy (FTIR). In: Nelson WH (ed) Modern Techniques for rapid microbiological analysis. VCH, New York, pp 43-96

Neus Anglès M, Reguant J, Garcia-Valls R, Salvadó J (2003) Characteristics of lignin obtained from steam-exploded softwood with soda/anthraquinone pulping. Wood Sci Technol 37:309-320

Newman MF, Burgess PF, Whitemore TC (1996) Manuals of dipterocarps for foresters, Philippines.. Center for International Forestry Research, Jakarta, pp 47-53

Nuopponen MH, Wikberg HI, Birch GM, Jääskeläinen AS, Maunu SL, Vuorinen T, Stewart D (2006) Characterization of 25 tropical hardwood with Fourier transform infrared, ultraviolet resonance Raman, and 13C-NMR cross-polarization/magic-angle spinning spectroscopy. J Appl Polymer Sci 102:810-819

Onuorach EO (2000) The wood preservative potentials of heartwood extracts of Milicia excelsa and Erythrophleum suaveolens. Bioresource Technol 75:171-173

Pandey KK, Pitman AJ (2003) FTIR studies of the changes in wood chemistry following decay by brownrot and white-rot fungi. Intern Biodeterior Biodegr 52:151-160

Parker PS (1983) Application of Infrared, Raman and Resonance Raman spectroscopy in biochemistry. Plenum press, New York, pp 21-25

Pastore TCM, Santos KO, Rubim JC (2004) A spectrocolorimetric study on the effect of ultraviolet irradiation of four tropical hardwoods. Bioresource Technol 93:37-42

Pastusiak R (2003) Charakterisierung von Zellstoffkomponenten- Analytik, Spektroskopie, Reaktionskinetik und Modellierung. Dissertation, Fakultät für Chemie der Technischen Universität München

Polle A, Otter T, Sandermann H (1997) Biochemistry and physiology of lignin synthesis. In: Rennenberg $\mathrm{H}$, Eschrich W, Ziegler H (eds) Plant physiology of trees. Backhuys Publishers, Leiden, pp 455-475

Pomar F, Merino F, Barcelo AR (2002) $O$-4 linked coniferyl and sinapyl aldehydes in lignifying cell walls are the main targets of the Wiesner (phloroglucinol/HCl) reaction. Protoplasma 220:17-28

Robert DR, Bardet M, Gellerstedt G, Lindfors EL (1984) Structural changes in lignin during Kraft cooking. Part 3: on the structure of dissolved lignins. J Wood Chem Technol 4:239-263

Saka S (2001) Chemical composition and distribution. In: Hon DN-S, Shiraishi N (eds) Wood and cellulose chemistry, Marcel Dekker, New York, pp 51-82

Santana MAE, Okino EYA (2007) Chemical composition of 36 Brazilian Amazon forest wood species. Holzforsch 61:469-477

Soerianegara I, Lemmens RHMJ (1994) Plant resources of South-East Asia. Timber tree: major commercial timbers. Prosea, Bogor, Indonesia

TAPPI T 204 om-88 (1987) Solvent extractives of wood and pulp

Vallet C, Chabbert B, Czaninski Y, Monties B (1996) Histochemistry of lignin deposition during sclerenchyma differentiation in Alfalfa stems. Annals Bot 78:625-632

Wagenführ R (1966) Anatomie des Holzes. VEB Fachbuchverlag, Leipzig, pp 156-159

Watanabe Y, Fukazawa Y, Kojima Y, Funada R, Ona T, Asada T (1997) Histochemical study on the heterogeneity of lignin in Eucalyptus species. I. Effects of polyphenols. Mokuzai Gakkaishi 43:102107

Watanabe Y, Kojima Y, Ona T, Asada T, Sano Y, Fukazawa Y, Funada R (2004) Histochemical study on the heterogeneity of lignin in Eucalyptus species. II. The distribution of lignins and polyphenols in the walls of various cell types. IAWA J 25:283-295

Wegener G, Strobel C (1991) Determination of phenolic hydroxyl groups in lignins and lignin fractions by means of FTIR spectroscopy. In: Proceedings of the second Brazilian symposium on the chemistry of lignins and other wood components. September 2-4. Campinas, SP, p 12

Whetten RS, Mackay JJ, Sederoff RR (1998) Recent advances in understanding lignin biosynthesis. Annu Rev Plant Physiol Plant Mol Biol 49:585-609

Whitemore TC (1984) Tropical rain forests of the far east, Second edition edn. Clarendon Press, Oxford, pp $1-14$

Wiesner J (1878) Note über das Verhalten des Phloroglucins und einiger verwandter Körper zur verholzten Zellmembran. Sitzungsberichte der kaiserlichen Akademie der Wissenschaften Math Nat Classe 77:60-66

Windeisen E, Wegener G, Lesnino G, Schumacher P (2002) Investigation of the correlation between extractives content and natural durability in 20 cultivated larch trees. Holz Roh- Werkst 60:373-374 